\title{
PERCEPATAN JURNAL KEWIRAUSAHAAN DAN BISNIS MENUJU AKREDITASI NASIONAL
}

\section{Susantiningrum, Eddy Triharyanto, Bara Yudhistira, Dimar Hantari}

\author{
Pusat Pengembangan Kewirausahaan LPPM Universitas Sebelas Maret, Jl. Ir. Sutami No.36A, \\ Kentingan, Surakarta, Indonesia, 57126 \\ Email: susantiningrum@staff.uns.ac.id
}

\begin{abstract}
Abstrak
Jurnal Kewirausahaan dan Bisnis (JKB) telah memiliki ISSN cetak dan ISSN elektronik. Pada tahun 2017 telah dilakukan kegiatan sosialisasi JKB untuk mempublikasikan jurnal tersebut ke seluruh wilayah Indonesia serta untuk menjaring penulis yang lebih bervariatif khususnya yang berasal dari luar Universitas Sebelas Maret (UNS). Selanjutnya diperlukan kegiatan pengembangan JKB menuju jurnal bereputasi dengan mengadopsi peraturan Ditjen Dikti Nomor 1 Tahun 2014 tentang Pedoman Akreditasi Terbitan Berkala Ilmiah. Penelitian ini bertujuan untuk meningkatkan kualitas manajemen dan pengelolaan pusat studi khususnya dalam mengelola Jurnal Kewirausahaan dan Bisnis menuju jurnal bereputasi yaitu dengan mempersiapkan syarat-syarat akreditasi jurnal nasional. Kegiatan yang telah dilakukan antara lain: koordinasi awal kegiatan, submit ke lembaga indeks nasional, workshop simulasi penilaian jurnal menuju akreditasi nasional, dan workshop program percepatan akreditasi nasional JKB.
\end{abstract}

Kata Kunci: jurnal, institusi, kewirausahaan, akreditasi

\begin{abstract}
Jurnal Kewirausahaan dan Bisnis (JKB) has p-ISSN and e-ISSN. In 2017 JKB socialization activities were carried out to publish the journal to all regions in Indonesia and to attract more varied writers, especially those from outside Universitas Sebelas Maret (UNS). Furthermore, JKB development activities are needed towards reputable journals by adopting the Direktorat Jenderal Pendidikan Tinggi Regulation No. 1 of 2014 concerning Accreditation Guidelines for Scientific Issues. This study aims to improve the quality and capacity of management study centers, especially in managing Jurnal Kewirausahaan dan Bisnis towards reputable journals, such as by preparing national journal accreditation requirements. Activities that have been carried out included: initial coordination of activities, submitting to the national index institute, workshop on simulation of journal appraisal towards national accreditation, and workshop on the national accreditation program for JKB.
\end{abstract}

Keywords: journal, institution, entrepreneurship, accreditation 


\section{PENDAHULUAN}

Kewirausahaan merupakan salah satu program unggulan di Universitas Sebelas Maret (UNS). Hal tersebut diimplentasikan dalam salah satu budaya kerja UNS yaitu Entrepreneurship. Dalam rangka mendukung program-program unggulan UNS khsususnya dalam bidang kewirausahaan, Pusat Pengembangan Kewirausahaan (PPKwu) Lembaga Penelitian dan Pengabdian kepada Masyarakat (LPPM) Universitas Sebelas Maret (UNS) memiliki Visi menjadi pusat riset dan layanan yang profesional, unggul dan terdepan di bidang kewirausahaan dan pengembangan bisnis bagi warga kampus dan masyarakat. Adapun misinya yaitu: 1) mewujudkan institusi PPKwu yang handal dan terpercaya; 2) membudayakan

dan mengimplementasikan

nilai-nilai kewirausahaan dalam kehidupan warga kampus dan masyarakat; 3) menumbuhkan wirausaha-wirausaha baru dari kalangan terdidik; 4) mewujudkan pelaku bisnis mikro, kecil, menengah, dan koperasi yang profesional, mandiri dan inovatif yang berwawasan iptek; 5) mewujudkan pusat kepakaran dalam bidang kewirausahaan dan pengembangan bisnis.

Telah banyak hasil-hasil penelitian dan pengabdian di bidang kewirausahaan yang dilakukan oleh PPKwu dalam rangka menjadi pusat mandiri professional yang bergerak di bidang kewirausahaan. Bentuk profesionalitas yang telah dilakukan adalah menerbitkan Jurnal di bidang kewirausahaan yang diberi nama "Jurnal Kewirausahaan dan Bisnis". Jurnal Kewirausahaan dan Bisnis ini telah terbit mulai tahun 2007 dan pada tahun 2008 telah memiliki ISSN cetak. Sedangkan versi elektronik telah diterbitkan mulai tahun 2015 dan pada awal tahun 2017 e-ISSN sudah terbit. Jurnal Kewirausahaan dan Bisnis versi elektronik ini menjadi salah satu bagian dari Jurnal UNS yang dapat diakses melalui

https://jurnal.uns.ac.id/index.php?journal= kewirausahaan-dan-bisnis

Sebagaimana terbitan berkala ilmiah nasional lainnya, Jurnal Kewirausahaan dan Bisnis juga memiliki beberapa permasalahan utama yaitu belum memperhatikan indeksasi. Permasalahan utama pengelolaan terbitan berkala ilmiah di Indonesia yang belum terindeks di pengindeks bereputasi adalah:

a. visibilitas dan aksesibilitas terbitan berkala ilmiah belum baik karena belum menerapkan manajemen terbitan berkala ilmiah secara daring (online);

b. proses pengelolaan tulisan ilmiah belum menerapkan standar-standar ilmiah;

c. kualitas penerbitan terbitan berkala ilmiah sebagian besar masih kurang baik;

d. pengendalian kualitas terbitan berkala ilmiah melalui proses penelaahan oleh mitra bebestari dan pemapanan gaya selingkung belum konsisten;

e. kualitas substansi artikel belum 
dijaga dan dipertahankan dengan baik.

Mengacu permasalahanpermasalahan tersebut, maka PPKwu berupaya melakukan perubahan manajeman pengelolaan Jurnal Kewirausahaan dan Bisnis menuju Jurnal Bereputasi. Penelitian ini bertujuan untuk meningkatkan kualitas dan kapasitas manajemen dan pengelolaan pusat studi khususnya dalam mengelola Jurnal Kewirausahaan dan Bisnis menuju jurnal bereputasi yaitu dengan mempersiapkan syarat-syarat akreditasi jurnal nasional.

\section{METODE}

1) Mengikuti lembaga pengindeks nasional

Dalam rangka memenuhi salah satu persyaratan untuk akresitasi nasional, maka JKB harus masuk dalam salah satu lembaga pengindeks nasional seperti Indonesian Scientific Journal Database (ISJD), Portal Garuda, Pustaka Iptek dan/atau yang setara. Dalam hal ini JKB akan melakukan pendaftaran ke Portal Garuda.

2) Workshop simulasi penilaian jurnal menuju akreditasi nasional Kegiatan ini bertujuan untuk menghitung kekuatan dan kelemahan JKB kaitannya dengan pendaftaran akreditasi nasional. Narasumber utama diharapkan dapat memberikan gambaran simulasi yang mendekati kenyataaan. hasil dari kegiatan ini akan digunakan sebagai dasar untuk menetapkan programprogram penataan dan pengelolaan JKB lebih lanjut menuju jurnal bereputasi.

3) Workshop Program Percepatan Akreditasi Nasional JKB

Kegiatan ini menindaklanjuti hasil dari workshop sebelumnya, terutama untuk meningkatkan kekuatan JKB menuju akreditasi nasional. Kegiatan ini melibatkan seluruh tim redaktur, pengelola dan mitra bestari JKB. Diharapkan hasilnya adalah tersusunnya program percepatan JKB menuju akreditasi nasional.

4) Menerbitkan dan mempublikasikan Jurnal Kewirausahaan dan Bisnis ke seluruh Indonesia

Versi cetak JKB maka di sosialisasikan ke perguruan tinggiperguruan tinggi di Indonesia.

\section{HASIL DAN PEMBAHASAN}

Kegiatan penelitian yang telah dilakukan pada tahun 2018 ini antara lain:

1. Koordinasi kegiatan awal

Untuk mengetahui permasalahan-permasalahan dalam pengelolaan jurnal ini perlu diadakannya koordinasi tim, yang terdiri dari tim peneliti, penanggungjawab jurnal, editor dan mitra bestari. Dari hasil koordinasi awal, diketahui bahwa untuk menuju jurnal terakreditasi diperlukan langkah-langkah awal seperti harus terindeks di lembaga indeks nasional serta melakukan 
penilaian mandiri terhadap jurnal. Adapun kegiatan-kegiatan yang akan dilakukan antara lain:

a. Melakukan submit Jurnal Kewirausahaan dan Bisnis ke lembaga indeks nasional dalam hal ini adalah Portal Garuda.

b. Workshop simulasi penilaian jurnal menuju akreditasi nasional internal yang dilakukan sekitar bulan Mei-Juni 2018.

c. Workshop Program Percepatan Akreditasi Nasional JKB yang dilakukan sekitar bulan Juni-Juli 2018.

d. Workshop simulasi penilaian jurnal menuju akreditasi nasional dengan mengundang narasumber eksternal dari Ristekdikti untuk menilai dan memberi masukan.

e. Menerbitkan dan

mempublikasikan Jurnal Kewirausahaan dan Bisnis ke seluruh Indonesia.

2. Submit ke lembaga indeks nasional Salah satu syarat jurnal terakreditasi adalah harus terindeks di lembaga indeks nasional, oleh karena itu tim peneliti telah mencoba untuk mensubmit ke salah satu lembaga indeks nasional yaitu Portal Garuda. Namun sampai saat ini belum ada konfirmasi dari lembaga pengindeks tersebut. Saat ini, total jurnal yang terakreditasi oleh Dikti tidak lebih dari 10\% (Nashihuddin dan Aulianto, 2016).

3. Workshop simulasi penilaian jurnal menuju akreditasi nasional
Workshop ini dilaksanakan pada tanggal 28 Juni 2018. Penilaian jurnal ini dilakukan oleh internal tim peneliti dan tim jurnal. Hasil dari workshop ini didapatkan nilai total 49 yang berarti terbitan berkala ilmiah yang tidak terakreditasi. Penilaian terdiri dari 8 (delapan) unsur, yang merupakan kriteria untuk menentukan peringkat dan status akreditasi suatu terbitan berkala ilmiah. Unsur penilaian tersebut antara lain:

a. penamaan terbitan berkala ilmiah,

b. kelembagaan penerbit,

c. penyuntingan dan manajemen pengelolaan terbitan,

d. substansi artikel,

e. gaya penulisan,

f. penampilan,

g. keberkalaan, serta

h. penyebarluasan.

4. Workshop Program Percepatan Akreditasi Nasional JKB Workshop ini dilaksanakan pada tanggal. Hasil dari workshop ini ditemukan beberapa hal yang perlu diperbaiki dan ditambahkan antara lain:

1. Pembuatan SK Universitas/Lembaga terkait eksistensi Jurnal Kewirausahaan dan Bisnis.

2. Penambahan mitra bestari dari luar institusi. Saat ini JKB baru memiliki 2 mitra bestari dari Universitas Lampung dan Universitas Pendidikan Ganesha. 
3. Penambahan nomor penerbitan di setiap naskah.

4. Setiap artikel dilengkapi dengan copyright transfer agreement dan publishing ethnical statement.

5. Proses submit, review, perbaikan harus full melalui website. Saat ini proses masih manual malalui email.

6. Bukti penerbit melakukan pengecekan plagiarisme.

\section{Workshop Pembuatan Template Jurnal}

Sejak tahun 2012, jurnal kewirausahaan dan bisnis hanya memiliki petunjuk penulisan artikel yang sifatnya kurang komunikatif sehingga agak membingungkan author untuk menyesuaikan tulisannya dengan format Jurnal Kewirausahaan dan Bisnis. Oleh karena itu, perlu adanya perbaikan petunjuk penulisan artikel dengan merubahnya menjadi template yang sifatnya lebih komunikatif, mudah dipahami dan diikuti. Hasil workshop tertera pada lampiran.

\section{Pelatihan OJS}

Saat ini, Jurnal Kewirausahaan dan Bisnis telah masuk kedalam system OJS Universitas Sebelas Maret. Untuk meningkatkan pengetahuan reviewer, editor, dan pihak lain yang terkait maka perlu dilakukan pelatihan OJS. Menurut Lukman et al., (2016; 2017), OJS melibatkan tujuh peran mulai dari proses submission sampai diterbitkan. Peran tersebut antara lain pengarang, editor, editor bagian, mitra bestari, copy editor, layout editor, dan proofreader.

\section{Publikasi Jurnal}

Publikasi dilakukan untuk mengenalkan Jurnal Kewirausahaan dan Bisnis ke seluruh Indonesia. Diharapkan dengan publikasi ini semakin banyak naskah yang masuk dari luar Universitas Sebelas Maret, yang nantinya akan meningkatkan nilai akreditasi Jurnal Kewirausahaan dan Bisnis.

\section{KESIMPULAN}

Berdasarkan hasil kegiatan, dapat disimpulkan bahwa kegiatan telah berjalan dengan persentase $100 \%$. Berdasarkan hasil simulasi, nilai JKB hanya 49 maka perlu dilakukan kegiatan untuk meningkatkan kualitas JKB.

\section{DAFTAR PUSTAKA}

Jurnal Kewirausahaan dan Bisnis. https://jurnal.uns.ac.id/index.php?j ournal=kewirausahaan-danbisnis\&page $=$ index .

LIPI. 2014. Peraturan Kepala LIPI Nomor 3 Tahun 2014 Tentang Pedoman Akreditasi Terbitan Terbitan Berkala Ilmiah. Jakarta.

Lukman, Sumirat, D., Atmaja, T.D. 2016. Manajemen Jurnal Elektronik (e-Journal), modul, materi ini disiapkan untuk pendirian jurnal "Indonesian Journal of Documentation and Information Science". ISIPII, UI, 18-19 Februari 2016, Depok. 
Lukman, Atmaja, T.D., Hidayat, D.S. 2017. Manajemen Penerbitan Jurnal Elektronik. Jakarta: LIPI Press.

Nashihuddin, W., Aulianto, D.R. 2016. Pengelolaan Terbitan Berkala
Ilmiah Sesuai Ketentuan Akreditasi: Upaya Menuju Jurnal Trakreditasi dan Bereputasi Internasional. Jurnal Pustakawan Indonesia, 15 (1-2): 83-98. 